Flows, Circulations and their Opposites:

Ethnographic Perspectives and Theoretical-Methodological Challenges

Bodies and (in) flows

\title{
"When I discovered I was índia": racialization processes in the migratory experiences of peruvians in Rio Janeiro
}

\author{
Camila Daniel $^{1}$ \\ 'Departamento de Ciências Administrativas e Sociais, Universidade Federal Rural do Rio de Janeiro, \\ Três Rios/RJ, Brasil
}

\begin{abstract}
In this article, I reflect upon the ways in which Peruvians in Rio de Janeiro negotiate their process of racialization, based on the category Indian and their interaction with me, a Black Brazilian woman. Despite the fact that Indian is part of both the Brazilian and Peruvian racial classification system, this category has particular meanings in each context. When they "discover" they are Indians", Peruvians face the specificities of anti-Indigenous racism in the urban context of Rio de Janeiro. They also deal with discrimination within the Peruvian community. This article analyzes the case of Peruvians who create self-definitions (Hill-Collins, 2016), both individually and collectively, that challenge stereotypes of peruanidad. Racialization also opens up possibilities for anti-racist solidarity between Peruvians and Black Brazilians. My research is based on ethnographic fieldwork carried out in Brazil and the United States from 2011 to 2016.
\end{abstract}

Key words: anti-Indigenous racism, inter-ethnic relations, South-South migration, decoloniality. 


\section{"Quando me descobri índia": \\ processos de racialização na experiência migratória de peruanos no Rio de Janeiro}

\section{Resumo}

Neste trabalho, reflito como os peruanos no Rio de Janeiro negociam os processos de racialização a partir da categoria "í/indio" e sua interação comigo, uma mulher negra brasileira. Apesar de integrar o sistema de classificação racial brasileiro (índio) e peruano (indio), a categoria remete a significados particulares em cada contexto. Ao "se descobrir í/indio", os peruanos se deparam com as especificidades do racismo anti-indígena no contexto urbano do Rio de Janeiro e com as discriminações dentro da comunidade peruana. Neste artigo, analiso o caso de peruanos que elaboram autodefinições (Hill-Collins, 2016) individuais e coletivas que desafiam estereótipos sobre a peruanidad. Por outro lado, o processo de racialização também abre possibilidades de solidariedade anti-racista entre peruanos e negros brasileiros. Este artigo se baseia no trabalho de campo etnográfico realizado no Rio de Janeiro de 2011 a 2016.

Palavras-chave: racismo anti-indígena, relações inter-étnicas, migração sul-sul, decolonialidade.

\section{“Cuando me descubrí “índia”": procesos de racialización en la experiencia migratoria de los peruanos en Río de Janeiro}

\section{Resumen}

En este trabajo, reflexiono sobre las formas en que los peruanos en Río de Janeiro negocian los procesos de racialización, basado en la categoría “í/indio” y su interacción conmigo, una mujer negra brasileña. A pesar de presente en el sistema de clasificación racial brasileño (índio) y peruano (indio), la categoria tiene significados particulares en cada contexto. Al "descubrirse "índio"', los peruanos enfrenta las especificidades del racismo anti-indígena en el contexto urbano de Río de Janeiro. También tienen que lidiar con la discriminación dentro de la comunidad peruana. Este artículo analiza el caso de los peruanos que elaboran autodecisiones (Hill-Collins 2016) individual y colectivamente que desafían los estereotipos de peruanidad. Además, la racialización también abre posibilidades para la solidaridad antirracista entre peruanos y negros brasileños. Este artículo se basa en el trabajo de campo etnográfico realizado en Brasil y en los Estados Unidos del 2011 al 2016.

Palabras clave: racismo anti-indígena, relaciones interétnicas, migración Sur-Sur, decolonialidad. 


\title{
"When I discovered I was índia": racialization processes in the migratory experiences of peruvians in Rio Janeiro
}

\author{
Camila Daniel
}

\section{Introduction}

It was a Saturday afternoon Méier, Rio de Janeiro in 2017. Diana was at my house along with several other Peruvian friends and we were having one of our collective lunches. Ever since we had met each other in Sayari Grupo de Danzas Peruanas, our Peruvian folk dance group, we would often get together to eat and socialize. As the hostess, I had consulted with my friends about what they would like to eat. Following their suggestions, I opted to make chaufa rice, a popular Chinese-influenced dish in Peruvian cuisine. Looking at my bookcase, Beatriz, a Peruvian from Lima, became interested in one of the books: "When I Discovered I Was Black", by Bianca Santana (2015). Intrigued, she took the book down, and leafed through it, totally absorbed. Seeing this, Diana wanted to know what was in that book that Beatriz was perusing with such total concentration. I explained that the book featured reports of Black people who faced racism and thus started to build Black identities. I said to my Peruvian friends that those stories were important because, many times, Black people like me and those in the book were targets of racism, but couldn't find tools to express what we felt. For this reason, recognizing oneself as Black was not a given, but a process, a becoming (Souza 1983). With a bitter and mocking tone, Diana said: "I'm going to write a book like that, too! Mine will be called: When I discovered I was an Indian".

In the article below, I present initial reflections on how Peruvians in Rio de Janeiro negotiate the signs and meanings of race in their migratory experiences and in their interactions with me, a Black Brazilian woman. The article will analyze the actions and relationships built between Peruvians and me in the face of our racialization as Black (in my case) and Indian (in their case). Directed at our bodies, both categories transnationally subordinate us in the colonial hierarchy (Quijano 2000; Segato 2005). Despite this, they do not destroy our ability to act: either individually and collectively. Focusing on Peruvians who arrive in Rio de Janeiro as students, I will examine how these actions are collectively developed in the performance of and construction of identities: both based on Peruanidad and individual. This article is based on ethnographic fieldwork carried out during the preparation of my doctoral thesis (defended in 2013) and the post-doctoral research I carried out in 2016 in Brazil and the United States.

Aligned with a decolonial perspective, this work understands borders as an epistemic place of knowledge production, based on the experiences of subordinate subjects (Bernardino-Costa and Grosfoguel 2016). This has the potential to denaturalize race, identifying the (counter)miscegenationist political potential (Goldman 2015; 2014) of the encounter between Peruvians and myself. This work contributes to comparative racial studies in the Americas, which have historically focused compared and contrasted Brazil and the United States. It also allows us to reflect on how mobile subjects such as Peruvian students reveal Brazilian and Peruvian power structures silenced by both countries' national projects. I am grateful for the valuable comments of those who carefully read the first version of this text, allowing me to radically deepen my ethnographic and theoretical analyses. I am especially grateful to Ketty Laureano Aire, who, with her double identity as a Quechua Wanka and researcher, accepted to be my interlocutor in this work, offering generous analytical suggestions and the emotional support to make it possible. 


\section{What the eyes see: Racialization processes of Indians in Rio de Janeiro}

Grupo Negro Mendes plays an important role in marking the Peruvian presence in Rio's cultural scene. Created in 2002, it presents a repertoire of musical styles from the Peruvian coast. Attending Negro Mendes shows has become an important part of my social life. During one show in downtown Rio, I was accompanied by a couple of Black Brazilian friends and I mentioned that a Peruvian friend would also come. Talking to the same Black couple some weeks later, they commented that “your friend doesn't look like a Peruvian; he doesn't look like an Indian". Since the beginning of my research, I have been asked multiple time why I have become so close to Peru. During my doctorate, this question marked my relationship with my mentor, a white Brazilian. She tried to persuade me to quit my work with "Peruvians" in order to study "Latinos". Her efforts were in vain, however. In one of our last meetings before my defense, she finally surrendered, exclaiming: "Since I started mentoring you, I have become able to recognize a Peruvian at a glance!" - referring, of course, to Peruvians who have an Indigenous phenotype. The Pontifical Catholic University of Rio de Janeiro (PUC-Rio), where I completed my doctorate, receives a large number of graduate students from different Latin American countries, including Peru. At this mostly white university, Peruvians and other students who had an Indigenous phenotype attracted attention.

Diana is one of these Peruvians. She came from Arequipa to Rio de Janeiro in 2009 to do her master's degree at PUC-Rio. We met in 2012, when she joined the Sayari Danzas Peruanas Group. Diana's trajectory parallels migratory dynamics in Peru. In the last decades of the zoth century, the country suffered an intense economic and political crisis, which increased emigration (Altamirano 2000; Paerregaad 2008; Berg 2016). From 1990 to 2011, it was estimated that more than 2 million Peruvians left the country: some $8 \%$ of the population (INEI 2012). Diana married a Brazilian and recently gave birth to her first daughter. Diana's phenotypical characteristics long straight black hair, almond-colored skin, small, dark eyes with epicanthal folds, pronounced cheekbones - attract the attention of carioca eyes. In several of our conversations, Diana remarked to me that she felt irritated when she was called an "Indian". Sometimes, this term was accompanied by other questions: "Where are you from?”; “How long have you lived in Brazil?"; “When will you return to Peru?” Diana's discomfort is at its greatest when her husband's relatives (who are white) call her "Indian". Her husband complacently explains that his relatives don't intend to offend. His conciliatory tactics have minimized the feelings that the word evokes in Diana. She is thus denied the possibility of having her feelings validated and acknowledged (Hooks 2010).

During my research, I was often asked by my Brazilian interlocutors if I liked ceviche, an internationally known Peruvian dish and a mandatory presence at Peruvian events in Rio de Janeiro. They'd also ask if I have been to Machu Picchu or even if the Peruvians I studied were those who "played the flute" or who worked as "street vendors" in the city's commercial areas. In the early 200os, the Peruvian presence became visible in Rio de Janeiro through popular musicians playing Andean instruments and through informal merchants working on the streets of the city. During my doctorate, there were Peruvians who worked as artists and street traders, but the Ecuadorian presence also increased significantly in these economic niches.

Many of my Brazilian interlocutors were unaware of the significant presence of Peruvian university students in Rio, imagining that every Peruvian would necessarily be in the same class as the musicians and street traders they were familiar with. As university students (most of them from prestigious universities), the Peruvians I collaborated with live with Brazilians and individuals of other nationalities who have access to higher education, many of them members of the middle classes of Brazil or their countries of origin. Students assume a central role in the construction of the spaces for sociability where the meanings of peruanidad in Rio de Janeiro are negotiated (Daniel 2017), such as the Sayari Grupo de Danzas Peruanas. Over the years that this group met, all of its members were students, with the exception of two, who worked as street vendors. In their interactions with Rio, Peruvian students discover that they are also subject to different forms of discrimination. 
I almost always surprised my Brazilian interlocutors when I told them that, since the 196os, many Peruvians have come to Brazil as university students. Sharing information about Peru and the Peruvian community in Rio de Janeiro that I imagined Brazilians do not know, increased my feeling - and that of the Peruvians who knew me - that I am "not a Brazilian like the others". A co-worker of mine once commented that there were many Peruvian university students in Rio de Janeiro. This time, I was the one who was surprised! This was a white man, resident of Tijuca, who had many times proudly told me stories about his annual vacation in France. When I or other colleagues commented on our travels in Latin America, he used to react with disdain. A descendant of Portuguese and Italian immigrants, he is applying for citizenship in both countries, and intends to migrate to Europe when he retires. He explained that he did his doctorate in Statistics at PUC-Rio in the late 20oos, where he lived with Latin American students, including Peruvians. "Yeah!" he exclaimed. "At PUC there were a lot of cucarachas!". Cucarachas? Cockroaches? My wide eyes and contorted face betrayed my shock. Seeing my reaction, my coworker continued: "That's what we called the Latino students who studied with us." How would Diana and the other Peruvians who studied at PUC feel if they knew that they are called insects, I wondered?

Although Peruvian immigration to Brazil has never reached high enough numbers to receive as much visibility as Bolivian or Haitian immigration (Daniel 2013), it does presents important elements with which to reflect upon processes of racialization. Immigration played an important role in the construction of Brazil as a national project, especially up until the 1930s. During this period, immigration policy was also conceived as a means of "whitening" the Brazilian population, encouraging the use of Europeans replace Black Brazilians in the post-abolition workforce, as well as subordinating Afro-Brazilians in the Brazilian national project. Foreigners were considered to be important for the country's development and eugenic "cleansing", but they were also seen as a potential threat to national unity. For this reason, the foreign presence in Brazil was understood as something that needed to be diluted through processes of miscegenation and acculturation (Seyferth 1997; 1996). Under this ideological view of the Brazilian nation, unassimilated foreigners should behave like guests, whose presence depended on national interests (Sayad 1998; 1999). In his ethnographic work with Englishspeaking foreigners in Rio de Janeiro, Blanchette (2001) discusses how "gringos" often encounter a less cordial face of Brazilian society. This is manifested, for example, in the belief that foreigners should not have access the same rights as Brazilians, nor criticize Brazil.

The condition of foreigner, as pointed out by Sayad and Blanchette, can worsen when the person in question is not socially read as white. Analyzing cases from the United States, Grosfoguel and Maldonado-Torres (2008) explain that the Native Americans, Chicanos and Blacks have historically been located outside the American national project. Even when formally recognized as citizens, they face daily processes of exclusion. This exclusion is frequently characterized as racialization, with individuals positioned in racial hierarchies below "the line of being". Individuals located in the "zone of being" are recognized as humans with the rights, material resources, subjectivities, identities, epistemologies and spiritualities that this classification entails. Those located in the "zone of non-being" have their humanity (as subjects of law or of production of knowledge and identities) questioned or denied (Grosfoguel 2016: 10). Latin American immigrants are incorporated into American society in this "zone of non-being", as are Blacks, Native Americans, and Chicanos, but their condition is aggravated further by the status as foreigners. They live an experience of intersectional oppression (Hill-Collins, 2016).

Since I began my fieldwork, I have met Peruvians with different physical appearances, of different classes, and from different parts of the country. The more I lived with Peruvians, the more I confirmed that I could never recognize a Peruvian "just by looking", as my former mentor believed she could. I also observed that all the Peruvian consuls I met - in Rio de Janeiro, São Paulo, and Washington DC - were men and women who were socially read as white. I say "socially read", because their bodily signs - skin color, body shape, face features, 
hair type, and color - are closer to the European white ideal than any other. The marks of colonial domination (Segato 2010) are not as clear on their bodies. By contrast, none of the Peruvian street vendors I have met, to date, have been as "white" as that nation's consuls.

It is important to note that these bodily signs are being read by me, a Black Brazilian. Brazil, the country where I was born and in which I have spent most of my life is, like Peru, situated in the southern hemisphere of the Americas. In both Brazil and Peru, miscegenation played a central role in attempts to dominate Black and Indigenous populations. I clearly carry the marks of coloniality on my body: my African ancestry is apparent in the darker color of my skin, in my curly hair, in my curvy physical form. In spite of their human potential, Africans and their descendants (a category in which I include myself) were incorporated into the history of Brazil as a commodity to be exploited in the capitalist system. This story is reproduced in the present day by the modern nation state, which systematically denies me and other Blacks the right to be recognized as human. In the United States, a country based on hypodescendence and open racism (Gonzalez 1988) as a way to protect whiteness (Harrison 1995), it is likely that the consuls of Peru, although phenotypically white in my eyes, are socially read as not-white because they are Peruvian, a country represented as "non-white". As both my country and I are transnationally imagined as non-white, I occupy a place of double coloniality and this, of course, defines the lens through which I read racial realities. This lens was polished by the ways I am read racially and how I am treated by those who interact with me, including Peruvians in Rio de Janeiro. In the encounter of my experiences with those of Peruvians in Rio de Janeiro, we built a dialogue that allows us to rethink our places in transnational processes of racialization.

\section{Transnational negotiations: í/indio and peruanidad}

In 2016, I conducted my postdoctoral research on how Peruvian immigrants in Brazil and the United States negotiate their identities through race. It was difficult to get my interlocutors to respond to the topic. Their answers were almost always evasive, accompanied by the statement that race does not matter in Peru, since "we are all mixed race". I decided to resort to the Brazilian census and the United States Social Security application archives to see what they turned up. Peruvians were often listed as "undecided", seeing that the Brazilian and American categories did not make sense to them. This "lack of meaning" was even more observable among those interlocutors who recognized their own Indigenous ancestry. Both "Indigenous" in Brazil and "American Indian" in the United States sounded strange to the ears that learned that "indio" (Spanish for "Indian") is an offensive term. One of my interviewees in Rio de Janeiro even commented that he thought it was inappropriate to ask a question about race. According to him, we are all human and talking about race was a way to divide humanity and thus reproduce racism.

Despite the difficulties of talking about it, race has been a central issue in my interaction with Peruvians in Brazil, the United States, and Peru. In my very first experiences with Peruvian events in Rio de Janeiro, some Peruvians confided to me (when they heard about my research) that there was a lot of racism within the community. On the other hand, Peruvians were much more reluctant to call the discriminations they suffered in their relationships with Brazilians "racism", probably because I am Brazilian myself. I also dealt with the racialized place that Peruvians attributed to me as a Black woman, when they identified similarities between Afro-Peruvians and me. This identification earned me the invitation to recite the poem "Me gritaron negra" (by Afro-Peruvian artist Victoria Santa Cruz) at the 2012 Fiestas Patrias ${ }^{1}$ (Daniel 2019).

The celebration of the independence of Peru, decreed on July 28th 1821, one of the most important events for the Peruvian community in Rio de Janeiro. 
I also experienced racial classification in folk dances, where the idea that Black dance is vibrant because Blacks are naturally happy is quite common. In the case of Peruvians in Rio de Janeiro, the main racial category which they need to negotiate was that of "indio".

When Diana is called "índia" in Rio, she is put into a racial category that also exists in Peruvian racial hierarchies (indio - without an accent). In both countries, this category refers to the colonial domination to which the Indigenous populations were subjected. The person classified as í/india is associated with tradition, backwardness, and an inability to fit into modernity, capitalism, and the nation-state. The meanings of the category have peculiar trajectories, however, being negotiated in different ways in each national context, as well as in the process of immigration. In Peru, "indio" combines several elements such as physical appearance, place of origin, education, ethnicity, class position, and residence within the rural world. In the community of Chitapampa ${ }^{2}$, in Cusco, De la Cadena (1992) observed that the category is negotiated in the relationship between the countryside and the city, in insertion in the world of labor, in access to property, and in marriage. Women, for example, are considered to be more "indio" than men because, among other reasons, the work they do in urban areas is not valued by men in Chitapampa. While women remain "india", occupying a place of inferiority in the community, men "amestizan". One way of doing this is by marrying a "misti": a member of the mestizo landowning class.

The formation of the Peruvian nation state set Indigenous peoples as "Others" within the nation. They were considered to be retarding the march towards progress (Degregori 1986). They were understood as having a primitive culture that should be either abolished in favor of modernity or protected to prevent its disappearance through acculturation (Golte 1995; Degregori 2012). De la Cadena (2006) demonstrates how this ideology inspired Peru's public educational policy, implemented since the beginning of the zoth century. This policy concealed a project of education that sought to incorporate Peruvian rural and Indigenous populations into modern life and national culture. This implied not only teaching the members of such populations to read and write, but also pushing them to abandon their "backward" cultural elements. De la Cadena reveals this State ideology in operation in Pedro, a book published by the Peruvian Ministry of Education in 1950 to teach adults to read and write. Pedro is a man who dresses Indigenous Andean clothes - chullo ${ }^{4}$, poncho and ojotas ${ }^{5}$ and who lives in the rural and mountainous Andes. He is married to a lady with long braids and the couple has two children. Throughout the book, Pedro's children are transformed: the daughter stops wearing braids and the son the chullo. The two children go to school. The transformation of the children represents formal education as a passage from the backwardness of Indigenous cultural references to the progress represented by modern culture and national identity. Education is thus understood to transform the children of Indians into mestizos, constructing a "myth of schooling as progress" (Degregori 1986).

In 1969, to better confront the exploitation of Indigenous labor on large rural estates, President Juan Velasco Alvarado implemented land reform in Peru. Alvarado also decreed the elimination of "indio" from the Peruvian vocabulary. With the destruction of latifundium and the subsequent redivision of land in rural areas, "indios" became "peasants" (Eguren 2015). This replacement of an ethnic-racial category (indio) with a class category (peasant), formal education, and agrarian reform did not eliminate anti-Indigenous racism from Peruvian society, however, either institutionally or interpersonally. Alvarado's measures neglected the cultural dimensions of systems of domination. At the same time, debates about whether or not one should use

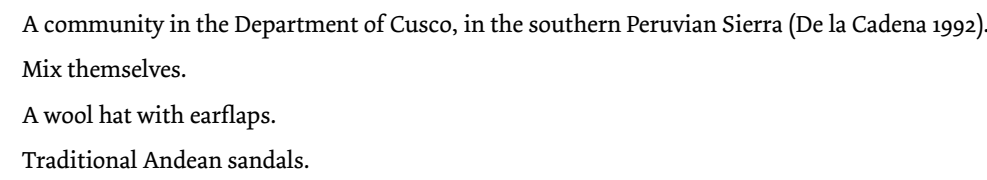


the term "indio" often make the Indigenous populations of the Peruvian Amazon invisible or considered as less developed than Andean Indians (Greene 2010). Interestingly, the search for higher and more prestigious levels of education is precisely the context which brings Peruvian students to Rio de Janeiro, where they encounter the classification "índio" as being applied to themselves.

In Brazilian common sense, "índio" is associated with poverty, ignorance, and the past. It is a category bound by village life and ruralness. In research into racism directed against Indigenous students at the Federal University of Amapá, Peixoto (2017) observed that non-Indigenous people believed that índios should not have access to universities or use electronic devices or western clothes unless they gave up their indigeneity. Native students suffer different forms of discrimination: classmates who refuse to work with them and teachers who refuse to mentor them. Additionally, those Natives who have Portuguese as their second language and who attended school in their villages faced barriers in both language and the Western model of teaching. These students experienced racism in both the intersubjective dimension in relationships with teachers and colleagues, and structurally, reproduced in teaching methodologies.

Analyzing the experience of Indigenous people in urban Rio de Janeiro, Bevilaqua (2017) narrates a series of events in which she witnessed the tensions generated when Cariocas questioned the identity of Natives in the city. She tells of cases involving white and Black Cariocas who demonstrate a stereotypical view of Natives. For example, Niara - one of Bevilaqua's interlocutors - was angered when a Black Brazilian told her that "Indians are all the same". Outraged, Niara argued that Blacks are not all the same either, but that most Black Brazilians do not know this as they do not research their own roots. For this reason, Black Brazilians do not know themselves and they project their ignorance upon Native people. Niara also believes the idea that "Indians are all the same" is propagated by television, which reproduces stereotypes about what it means to be Indigenous, denying Native people's diversity. Índios in Rio are thus pushed out of representations of Brazilianness or are reduced to images that represent Natives in the city or at the university as beings who are out of place.

Diana was born in one of the biggest cities in Peru. She has a high level of formal education and is not ethnically identified with any Native population. Since we first met in 2012, Diana has complained about being called "índia" in Rio de Janeiro and about the discrimination she faces. At her suggestion, Grupo Sayari staged a "Arequipeño Carnival": a manifestation of music and dance in the Arequipa ${ }^{6} \mathrm{Huayno}^{7}$ style at the 2013 Hispanidade Festival ${ }^{8}$. Before this, the Grupo generally performed the Valicha ${ }^{9}$, a dance of Huayno Indigenous origin from Cuzco. In addition to being well known by Peruvians, Valicha is from the region where the parents of the founder of the Grupo, Karina, were born. Before the Arequipeño Carnival, the Grupo had already envisioned the possibility of presenting a choreography set to Huaylarsh, an Indigenous rhythm from the central mountains of Peru. Difficulties in learning the dance and preparing the costumes for it made this plan unfeasible, however. Diana's suggestion to replace the Valicha with the Arequipeño Carnival was welcomed by all members of the group, including Karina and the three members from Cuzco. The same thing did not happen, however, when we talked about the need to include dances from Selva (the jungle region of Peru) in our repertoire to properly fulfill the Grupo's declared mission of "representing Peru" (Daniel 2015). This demand was severely criticized by the group's founder, who explained that she had unresolved emotional issues with people from that region.

\footnotetext{
6 This description of the carnaval arequipeño was created by the Grupo Sayari, referencing the music and dance traditions of Arequipa Carnival. For debate regarding the festival and the cultural expressions it encompasses, see Condori Huamani e Nina Escalante (2016).

7 A characteristic pentatonic musical style of the Peruvian Sierra, which has encountered in different forms in different regions.

8 This festival, organized by the Casa de Espanha, references the arrival of Christopher Columbus in the Americas. The Grupo's participation in this event generated great expectations, given that it was an opportunity for the Grupo to "represent Peru" in front of a multi-national public.

9 The classification of "Valicha" as huayno is according to Grupo Sayari de Danzas Peruanas. Conversing with a Peruvian sociologist who was researching Peruvian immigrants in São Paulo, I learned that this classification is debateable. A greater discussion of Peruvian musical styles is beyond the scope of the present article, however.
} 
At the same time that Diana was developing professionally as a production engineer, she was also participating in the expansion of the representation of the Peruvian Sierra through folk dances. She took the lead in researching the Arequipeño Carnival in order to teach us and inspire our choreography. By that time, the Grupo's rehearsals had migrated from Karina's house to Diana's house, both of which were located in the Vila Isabel neighborhood. The song we danced to was "Mambo de Machaguay". All Peruvian members of the Grupo - who at that time were from Lima and Cuzco - knew the song and liked the idea of choreographing it. Composed by Luis Abanto Morales, "Mambo de Machaguay" tells the story of a migrant who returns from Lima to Machaguay, his district of origin, in the Department of Arequipa. The young man brings with him mambo, a Cuban musical style, which he encountered during his migration to Lima. In the first two verses, the migrant says that he is returning from Lima to Machaguay, in the Sierra de Peru, to dance the mambo, a Cuban rhythm, with his "cholitay" ${ }^{10}$ (a way of referring to a woman with whom he has a loving relationship - the word is derived from chola). The song also features elements of the Quechua language, such as the "y" ending in "cholitay". The last two verses of "Mambo de Machaguay" are entirely in Quechua.

We put together the costume for this presentation, always one of the great challenges inherent in including new styles in our repertoire. We used the pollera" from the Valicha, and the men wore black pants, a white blouse, black shoes and a straw hat. To complete the production, the women combed their hair into two braids (much like those that Pedro's daughter, the character in the Peruvian literacy primer, undid when she started school). Of the four women who danced in the first Arequipeño Carnival performance, Diana was the only one who had hair long enough to braid. At one of the Grupo's collective lunches, her husband commented that Diana's long, straight, dark hair earned her the nickname of "Pocahontas" in Arequipa: the Powhatan woman who has been recently transformed into a Disney princess. All three other female members of the Grupo who danced in the Arequipeño Carnival - including myself - had to wear fake braids. In my case, wearing these led to an internal conflict: my hair has a deeply political meaning. On the one hand, I didn't want to feel that I was adhering to a stereotype of peruanidad. On the other hand, wearing fake hair hurt the political relationship I have with my hair, which at that time was in transition. ${ }^{12}$ Minutes before the presentation, I agreed to wear the fake braids.

In thinking about the Arequipeño Carnival performance as part of peruanidad, a relevant question is what is the place that Arequipa occupies in the imagination of Peruvians in Rio de Janeiro? The Arequipa department occupies an ambiguous geographical location, with part of its territory on the coast and another part in the mountains. Diana was born in the city of Arequipa, capital of the department, which is in the Sierra. The department is also known for its claim as independent from the rest of the country. During Peruvian events, this was often a reason for jokes between Peruvians from other regions and the Arequipeños. As an active member of the Grupo Sayari Danzas Peruanas, Diana found a place to feel welcomed in Rio and, at the same time, participate in the construction and performance of peruanidad as an Arequipeña.

By including the Arequipeño Carnival in the repertoire of Grupo Sayari, Diana gives recognition to the Indigenous presence in her Arequipe identity, despite not identifying as Indigenous herself. This expands the notion of peruanidad, challenging the centrality that the capital of Lima has in the Peruvian imagination. It also expands the representation of Peruvian Indigeneity in Rio de Janeiro, previously limited to Valicha and Cuzco. At the same time, Diana opened up to learning more about her own country through dance. Among the dances she learned was the Tondero. Originating in the region of Piura and Lambayeque in northern Peru, the Tondero is a dance containing Black, Indigenous and European influences representing the playful courtship

\footnotetext{
10 "Cholitay" is derived from chola, a word referring to women of Indigenous origin from the Peruvian Sierra The word can be employed both as a compliment or insult, depending on its context. Cholitay is composed of the diminutive form of this word - cholita - with the addition of a Quechua ending - $y$. Cholitay is thus a diminutive form combining Spanish and Quechua in the creation of an endearing term. 
of a couple. Diana saw Tondero for the first time in Rio de Janeiro and became interested in learning it. In 2015, Diana, myself, and another member of the Grupo danced Tondero at Fiestas Patrias. In 2016, Diana danced Tondero with her husband at their wedding party in São Paulo. I had ordered her all white tondero costume with her mother when I traveled to Arequipa in 2015. In her dancing, Diana thus demonstrates the alternatives she developed when she "discovered" she was "índia".

\section{Beyond "choleando": Performing race}

As a member of the Grupo Sayari Danzas Peruanas, Diana worked constructing peruanidad as an ethnic identity that recognizes regional particularities. The performance of the Arequipeño Carnival, brought the recognition of Arequipa as part of Peruvian culture to the stage. It also contributed to expanding the representations of the indigeneity that are parts of that culture. By presenting a Huayno from Arequipa, Diana and Grupo Sayari made public the notion that Peruvian Indigenous culture is not only Cuzco and Machu Picchu. This limited idea of Peru, which many Peruvians claim that Brazilians have, is also often reproduced by Peruvians in Rio de Janeiro. Da Cunha (2009) points out that ethnicity is constructed as a "culture of contrast" (p. 237), where a group selects elements of its culture to define its boundaries in relation to other groups. Ethnicity thus becomes a diacritical mark of identity, which does not encompass the completeness of a group's culture, but assume a central role in mediating the group's relations with outsiders (Barth 2000). The image of Machu Picchu and certain aspects of Quechua culture have become diacritical elements that mediate the relationship between Peruvians and Brazilians. This mediation often reinforces exotic stereotypes of the cultures and people of the Sierra Peruana.

An example of this is the appearance of "El Cholito" at Peruvian events in Rio de Janeiro. "El Cholito" is a costume that represents a "cholo", one of the terms applied to people of Indigenous descent from the Peruvian Sierra. "El Cholito" consists of the giant foam and fabric head of an Andean man. The costume gives physical form to stereotypical characteristics representing the physical and cultural dimensions of indigeneity: the chullo, with his fringe of black hair that slides over the his forehead and the eyes that are slanted up and to the sides. The person wearing the costume takes on the task of livening up the party, dancing and greeting everyone. When "El Cholito" arrives at parties, many people take pictures of it. On some occasions, "El Cholito" arrives accompanied by "Llamita", a costume of a giant llama head. These costumes threaten to solidify representations of Andean people and cultures by reinforcing stereotypes inside and outside the Peruvian community - stereotypes that can contribute to anti-Indigenous discrimination and racism.

Luis Fernando ${ }^{13}$ was shocked when he arrived in Rio de Janeiro in the late ' 90 s and realized that he was seen as an "índio". Originally from Tacna on the southern coast of Peru, he has white skin, wavy dark hair and is around six feet tall. He is not recognized as an "indio" in Peru. Thus, at the same moment that he began his trajectory of international student mobility - a way of validating his social ascension in Peru - he stopped being "mestizo", a position of racial power in Peru. Instead, he dropped in status, becoming an "índio" in Brazil. In Luis Fernando's case, his inclusion in this category was more associated with his nationality than strictly with his bodily characteristics. Luis Fernando discovered that, in practice, people are racially classified not only according to their physical type, but also according to their countries of origin. As a Peruvian who does not carry the bodily markers of colonial domination (at least as read through Brazilian lenses), Luis Fernando can escape racial demotion by keeping his nationality a secret. This is something that Peruvians like Diana cannot do. Even if she were to hide the fact that she is Peruvian, her phenotypic features would reveal her as non-white.

13 Luis Fernando arrived in Rio de Janeiro in 1996 as an undergraduate student. 
Performances of peruanidad in public spaces in Rio de Janeiro take on different forms. The Peruvian community in the city contains significant numbers of artists and professional cultural producers who build dialogues between different cultural expressions from Peru and other countries. In their work, these people employ the aesthetic, semantic, and symbolic resources of art. Some examples are actress Rosana Reategui, actor and musician Edison Mego, cultural producer Rocío Salazar, and musician Sergio Valdeos. Edison, for example, in addition to being an actor, is also part of the Grupo Negro Mendes, mentioned at the beginning of this article. The group plays a very important role inside and outside the Peruvian community in recognizing the Black presence as part of Peru, something many Brazilians are unaware of. On the other hand, the group also encounters stereotypes about what Black musical productions are supposed to be. Many Brazilians and Peruvians expect the group to have a "dance" repertoire. During parties and celebrations where the group plays, an Afro-Peruvian "style" - a festive, vibrant rhythm, with vigorous percussive elements that resonate in the body - tend to be more appreciated by a public that believes that Black music of any nationality has an obligation to entertain. Resisting this stereotype, the group maintains a diversified repertoire of traditional rhythms from the Peruvian coast, such as landó, vals, tondero and marinera. On its most recent album, released in 2016, the group explored the possibilities of mixing rhythms, employing what is in Peru classified as a fusión style.

Luis Fernando admits that his rejection of the term "índio" in Brazil is associated with the prejudice that he himself had against "indio" in Peru. He explains that social relations in Peru are organized through the "cholometer" or "indiometer", an informal "thermometer" that supposedly measures what degree of indigeneity a given person has. The "cholometer" considers such criteria as phenotype, clothing, place of origin, class, and education in making its determinations. The "cholometer" establishes social and racial hierarchies, defining how much recognition and respect each person is due, according to how far they are from the base of the hierarchy (where the indios are). Luis Fernando comments that Peruvians - both in Peru and Rio de Janeiro - are able to differentiate each other according to all these criteria, but that Brazilians are not.

Many Peruvian students in Rio de Janeiro with whom I lived and interacted with commented that Peruvians face discrimination from the Federal Police, banks, and other Brazilian institutions. Some explained that this was because of certain Peruvians' excessively courteous and even subservient posture - speaking softly, avoiding. eye contact. Some of my interlocutors went even further in their analysis, associating this "subservient posture" with "Indigenous culture", which is understood to be naturally sadder, more melancholy, downcast, and submissive. This representation of "Indigenous culture" contradicts the festive and irreverent spirit of the Arequipeño Carnival. By blaming other Peruvians for the discrimination they suffer, my interlocutors seem to be unaware that bodies that are farthest from whiteness are more subject to racism.

Discrimination within and from outside the community is not completely excluded from the debate in the public spaces built by Peruvian, however. The presentation of the poem "Me gritaron" at events such as the 2012 Fiestas Patrias and the shows by the Grupo Negro Mendes help Peruvians and people of other nationalities to get to know the work of Afro-Peruvian artists and to learn about anti-Black racism in Peru. The fact that I recited the poem also opened up the possibility of denouncing racism in Brazil. At the end of each presentation, I could hear people in the audience commenting on racism. Some of them came up to me afterwards in order to congratulate me on the performance and also to ask me questions. The Peruvian friend who accompanied me to the Negro Mendes show and my Brazilian friends said he "didn't look Peruvian, because he didn't look like an Indian" was the one who invited me to recite the poem. He always liked the poem, but there had never been a Black member in the dance group. He did not think it appropriate that the poem to be recited by someone who was not Black. Due to his phenotypic traits, my friend escapes the negative racialization faced by those who are socially read as "i/indios". Even so, he was moved by a poem that denounces anti-Black racism. By bringing this Afro-Peruvian poem to the Carioca stages, my friend, myself, Grupo Sayari and Grupo Negro Mendes 
opened up space for reflection on racism. This reflection made me want to learn more about Afro-Peruvian cultures and to participate more actively in the construction of a counterhegemonic vision of Peru in Rio de Janeiro. My interest culminated in the creation of the Encontro-Brasil in 2012 and its subsequent editions in 2014 and 2019. My participation in the Peruvian community as a Black woman also played an important role in my process of constructing my identity as a Latin American Black woman.

In 2013, the Consejo de Consulta ${ }^{14}$ and GEASUR ${ }^{15}$ organized the "Dialogues from El Sur - Discussing racism in Latin America" conference. The event took place at UNIRIO on a Saturday. In the morning, the film Choleando was shown, a documentary discussing racism in Peru and the different forms it takes. The name of the film is the gerund of the verb "cholear", which means the act of classifying a person as a cholo with the intention of oppressing him, as explained by Luis Fernando. The gerund indicates that the act of discrimination is dynamic and relational. In each interaction, individuals classify those who have more "Indigenous" traits - phenotypical, class, etc. - bringing them closer to subalternized subjects in Peru: cholos and black people. Cholear thus names the action of negatively racializing individuals in urban Peruvian contexts. This activity spread with the migration of rural populations from the Seirra to the capital Lima. It became a way of transforming the previously physical distance between the Lima elites and the populations of the Sierra (Sierra $x$ Costa) into racial distance. Cholear thus does not necessarily refer to a racial or ethnic identity, but to the dynamics of power relations that rank individuals in accordance with the intersections of their physical, cultural and class characteristics.

The event was followed by a lunch break. In the outer courtyard of the auditorium, stalls were installed selling Peruvian food. Different Peruvian cooks presented dishes for the public to taste. After lunch, a round table was held with 3 participants: Dr. Claudia Miranda (a Black Brazilian), Dr. Pedro Mireles (Peruvian), and myself. The debate was mediated by Nollan Montalvo, a member of the Consejo de Consulta. It ended with a presentation by Grupo Negro Mendes and Grupo Kuntur, which played songs with Andean cultural influences. The public actively participated in the entire event. Many members of the public regretted that they had little time to discuss things further with members of the table. the musical performances were received with applause and smiles and many members of the audience, excited, even ended up dancing. The friends who danced with me in the Grupo Sayari, Prof. Celso Sanchez, and I all got up to dance as well. Celso invited one of his friends to dance to the Valicha played by Grupo Kuntur while my friends and I danced during Grupo Negro Mendes' presentation. At the request of my friends who were members of the Consejo de Consulta, I recited the poem "Me gritaron negra".

Peruvian public events in Rio de Janeiro are usually organized using three elements as a reference: Peruvian food, music, and dance. These are the central three elements in the social construction of peruanidad in Rio de Janeiro and the negotiations around it (Daniel 2017). One of the effects of the large presence of students and artists in the Peruvian community in Rio de Janeiro is their role in organizing these sorts of public events. Many of these events take place at universities, research institutes, and theaters located in the Center and South Zone of Rio. These spaces are accessed through their organizers' contact networks, typically among middle class Cariocas. These spaces are not often frequented by those Peruvians engaged in more precarious jobs - particularly those which required a long workday -, who live in more distant neighborhoods, who do not have access to these networks, or who do not feel welcomed in spaces where middle classes predominate, Peruvian or Brazilian.

\footnotetext{
14 "The Consejo de Consulta was created in 2002 by the Peruvian Foreign Affairs Ministry to function as an associative and participatory organization for Peruvians living abroad, permitting the establishment of a dialogue between the Peruvian community abroad and the nation's consulates" (Daniel 2013:66).

15 Grupo de Estudos em Educação Ambiental desde el Sur, coordinated by Prof. Celso Sanchez, of the Escola de Educação of the Universidade Federal do Estado do Rio de Janeiro (UNIRIO).
} 
It is interesting to observe the guests at the debate panel organized for above mentioned event: two Black Brazilian women and two Peruvian men with Indigenous phenotypes. This may indicate both the recognition of the contribution of non-white researchers to the anti-racist debate, but it also shows that racism is a topic that those people closest to whiteness will generally not talk about. On the other hand, Prof. Celso Sanchez, who is a white man, participated in the event performing production tasks such as assisting with the image and sound equipment. He thus contributed to the event without assuming any visibility roles. "Dialogues from El Sur" created an interactive environment, bringing Peruvians from the middle and lower classes into the university space. Of all the Peruvian events that I had attended, participated in as a dancer, or even organized, this was the first time that I saw such a diverse Peruvian audience in a university. The event also had a Brazilian audience, which was mostly linked to GEASUR and its partners from other universities. The event attracted Brazilians and Peruvians with food and dance, but it also managed to create a space where everyday racism was named, discussed, and criticized.

\section{Becoming Quechua Wanka: The (re)construction of racial identity in the Peruvian migratory experience}

In my doctoral thesis, I developed the notion of "migratory experience", understood as "a set of experiences that, provided by the simultaneous displacement through different symbolic and geographical spaces, allow individuals to cast a critical eye on themselves, their practices, their country of origin, and their destination" (Daniel 2013). The notion helped me analyze how Peruvian students understood their shift from Peru to Rio de Janeiro in the context of migration. It also recognizes the specificities of student mobility compared to other forms of mobility, such as immigration or seeking refuge. For many Peruvian students, coming to Rio de Janeiro also meant rethinking their relationship with race. Born in Junín in central Peru and having migrated to Lima as a child, Ketty Aire Laureano came to Rio de Janeiro to study. In 2015, she entered into the master's degree program in Communication and Culture at UFRJ, defending her dissertation in 2017.

Ketty and I met in 2015 at the Peruvian gastronomy festival Expo Ceviche, which took place at the Casa de Espanha. She had already sent me an email saying she was interested in studying Peruvian immigration in Rio de Janeiro, but we had not yet met in person. I was in line to buy my ceviche when Ketty approached with a hearty smile. "Are you Camila?" she asked. “Yes, I am," I responded, also smiling. Ketty told me about her research plans and I expressed my joy that more people would be working with Peruvian immigration in Rio de Janeiro. In 2016, Ketty and I became even closer. This was the year that I did my post-doctorate in the United States, mentioned above. In addition to being one of my interviewees, Ketty conducted interviews with other Peruvians in Rio de Janeiro and also transcribed interviews. She also helped my undergraduate research assistant. Finally, I had the honor of being on Ketty's dissertation defense committee, at her invitation.

I interviewed Ketty over skype. At the time, I was living in Baltimore, a mostly Black city north of Washington D.C. There, I was systematically rejected by Peruvians, who read me as an African American. This rejection was often manifested by silent expressions of hostility, such as inquisitive looks. Sometimes the rejection came in a passive-aggressive way, with hypocritical praise, followed by demeaning comments about my body, my intellectual capacity or my morals. Each time this happened, I felt pain and anger. The silent or ambiguous character of Peruvian racism towards myself left me confused and full of doubts, with no resources to resist it. It took me a few months to understand that I was suffering from racism. This only happened after I joined an art-activism collective in Baltimore that socialized concepts about racism in order to politicize our experiences (Daniel 2019). 
Ketty claimed that, like Diana, she does not feel at ease in Rio de Janeiro. Comparing her Carioca life with her Peruvian experiences, she reflected that she is more exposed to discrimination in Brazil; she does not have a support network and is not represented in the city's spaces of power. As an example, Ketty cited the university which she attends. While in Peru, she found many teachers and students with whom she identified, at least phenotypically. In Rio de Janeiro, she feels isolated and therefore more vulnerable. In the interview, she confided that she feels intimidated at the university. I told her that I had the same feelings, which indicated that our sensations were not episodic, but part of the power structure built into and around us. Ketty's phenotype brown skin, straight black hair, short stature - situates her on the non-white side of the racial hierarchy. The racialization is aggravated by her Peruvian and Andean accent. While Diana found a way of expressing herself in the Arequipeño Carnival, Ketty did the same thing in her dissertation: "We are discriminated against in both public and private venues by officials, police, teachers, drivers, politicians, and government officials" (Aire 2017, p. 90).

Ketty acknowledges that there is racism in Peru, but says that she did not feel she was in a minority there. In Lima, Ketty navigated geographic and social spaces with people who looked much like her. At the university in Lima, for example, her colleagues and teachers were also "cholos". In Rio, Ketty circulates in spaces mainly occupied by the white elite. She feels that her body is rejected in these spaces. This is very similar to the discrimination I suffered in Peruvian spaces in the United States. Ketty reports that the discrimination she faces in Rio is almost never verbalized. Even so, it is effectively materialized in looks of disgust and paternalistic acts. Ketty points out that the Indigenous ancestry in her body breaks the order of the white spaces of Rio's elites. Since coming to the city, the young Peruvian has faced different forms of racism. Shortly after her arrival, she was intercepted on the subway by a man who, looking at her, asked if she was on her way to the city Center to sell stuff. Ketty didn't understand the question. When she got off the subway, however, she quickly understood: in downtown Rio she found numerous street vendors with a phenotype similar to her own. Most of the vendors were Ecuadorians. At that time, Rio was receiving significant numbers of Ecuadorian immigrants involved in street commerce (Vieira 2014). On another occasion, Ketty, her boyfriend and two other Peruvian friends was harassed by an Uber driver. When Ketty's boyfriend tried to close the car's window, the driver shouted at him: he ordered the window to remain open, because the Peruvians "stank" (p.14).

For her master's dissertation, Ketty analyzed the migratory processes of Andean migrants in Rio de Janeiro. I was surprised and also a little disappointed. As there is no other study on Peruvian immigration in Rio de Janeiro, I had hoped that Ketty would write about some of the various issues that I was able to observe in the field, but had no time to analyze. In one of our conversations, Ketty told me that she noticed many similarities in her interaction with Peruvians, Bolivians, and Ecuadorians of Andean descent in Rio. Many of these immigrants also suffered discrimination because of their phenotype and accents. Ketty was also not comfortable in predominantly white and mixed-race Brazilian and Peruvian spaces. She associated her choice of her research object with the racism she had suffered at the hands of the Uber driver. "The driver was about 24 years old. He was white. He, a white man, did not believe he was working, even less so for 'Indigenous', 'poor' and who 'stink'. For this reason, my research ended up being a personal and demanding project, a struggle for the recognition of the cultural diversity of us, Andeans, because in no way are we 'all the same"(p.14) .

With great sensitivity, Ketty narrates the feelings emerged during the Uber case. She felt "a mixture of fear, panic, helplessness, anguish, despair, terror". The driver's screams expressed his "anger, wrath, and resentment". Ketty emphasizes the importance of these feelings in revealing power structures that are often silenced. Rocha (2014) notes similar feelings in the movement of mothers whose children were murdered by the police in Rio de Janeiro. Feelings such as indignation, pain, and longing form the parameters of their to fight for justice. In their struggle, these mothers reveal the anti-Blackness reproduced by the State. In addition to killing their children, states makes it almost impossible to punish the guilty. Thus, it refuses to recognize 
the mother's citizenship and, ultimately, their humanity. Along these lines, Rocha (2014) develops what she calls the "Anthropology of Outrage". In the same way as Ketty and Rocha, I have analyzed the importance of racialized anthropologists validate their feelings as criteria for analysis and execution of fieldwork from an autoethnographic perspective (Daniel 2019). In the article, I analyze the most serious case of racism I faced in fieldwork with Peruvians in the United States, when I found myself in physical danger. I discuss how much silent racism - which I suffered from Peruvians, but also in my life in Brazil - affected my ability to validate my feelings. These feelings are fundamental to the establishment of the limits of how much I, as a Black anthropologist, should expose myself in the fieldwork while refusing racism. The authors above also offer us elements to reflect upon the different forms that whiteness is reproduced in national and transnational contexts, at both institutional and interpersonal levels.

It is interesting to note that the debate about racism in Brazil tends to focus on the relationships between whites and Blacks (McCallum, Restrepo and Reesink 2017). If anti-Indigenous discrimination were to be called "racism", a transnational alliance could be created between Black and Indigenous peoples against the racial inequalities that preserve white privileges (Bento 2014) in Latin America. A good example of the kinds of connections that could be made can be seen in Brazilian Indigenous university students' recognition that the discrimination they suffer is racism. This has led these students to repudiate discrimination using, as a legal reference, the Brazilian laws that classify racism as a crime (Peixoto, 2017). The experience of the racialization of Black and Indigenous bodies is also something that should not be restricted to intranational space. Often, national identities spread abroad as ethnic identities reproduce the oppressions of their countries of origin, relegating Black and Indigenous immigrants to subordinate roles in their national community overseas. This subordination is often expressed in the refusal of the recognition of Black and Indigenous people as part of the immigrant community, or by their inclusion as exotic or inferior.

Although she has never denied his Indigenous ancestry, living in Brazil is making Ketty reconsider how she identifies herself in racial terms. An important episode in this process was the day she enrolled for the master's selection exam at the Postgraduate Program in Anthropology at the National Museum. The Program had already created an affirmative action policy, guaranteeing vacancies for self-declared Black and Indigenous candidates. "The Indigenous line is on that side," said one candidate when she saw Ketty trying to register. With her form in hand, Ketty hesitated before responding to the interrogation, "what is your race / color?" It was the first time that she faced with such a question. Initially, Ketty resisted the question. She refused to go to the "Indigenous" queue. She also found the question about "race / color" to be inappropriate. "Don't you have a 'human' option?", she asked, in a mocking tone.

For both of us, being a racialized migrant presented the challenge of dealing with racial classification systems whose codes we did not know. Neither of us accept the place of subordination to which we are assigned. Resignifying race as a force for transforming subordinate subjects into free ones (Segato 2010), we each built a path that led us to review our identities and our political positions. Ketty notes that she and her other friends face difficulties in finding a space in Rio de Janeiro that accommodate their reflections on the racism they suffer in Brazil. Such a space is rare in both the Peruvian community and in Brazilian society at large. Ketty has been looking for references in Brazilian Black thinkers and activists. In 2019, she enrolled in the "English and Social Justice" course, an English course that focuses on social, racial, and gender justice ${ }^{16}$. Ketty told me that she became interested in the course after seeing it promoted on my Facebook profile. She also participates in Magdas Migram, a collective of migrant women formed around the methodology of the Theater of the Oppressed.

16 A class created by Priscilla Pinto Ferreira, a post-doctoral student in the Department of African and African Diaspora Studies of the University of Texas and a Black Brazilian political activist. 
When reading the first version of this article, Ketty asked me to make some corrections. She rejected the term "india", but accepted "chola" and "Andean '. Now, she accepts terms like "india”, "Indigenous", "serrana”, and "chola", but rejects the violent and paternalistic ways in which they are often employed. Today, Ketty encompasses her identities in one sentence: "soy quechua wanka." Recognizing herself as wanka, an ethnic group from the Junín region, and Quechua, Ketty situates herself in the ethnic diversity of populations of Quechua origin, often ignored in hegemonic representations of the Andeans. The dialogue between Ketty and I has enabled us to share emotional and political support, as well as theoretical reflections from an AfroIndigenous perspective (Goldman 2015; 2014) as racialized women and researchers. We have proposed an article for the $32^{\text {nd }}$ Meeting of the Brazilian Anthropological Association, where we will draw parallels between our experiences as racialized researchers in transnational contexts. As outsiders-within (Hill-Collins, 2016), we hope to contribute to unraveling anti-Black and anti-Indigenous racisms in Latin America.

\section{Final Remarks}

In expressing her need to write a book to tell "how she discovered herself to be índia", Diana reveals the classification power Brazilian society wields over her. She also reveals the pain of being silenced when she shares how it feels to be incorporated into a lower category in the Brazilian and Peruvian racial hiearchies. Many Brazilians overlook this pain, including some with whom Diana has intimate relationships. In the book on my bookshelf, Diana found an opportunity to relate her experiences of discrimination, as a Peruvian with an Indigenous phenotype in Rio de Janeiro, to those Black Brazilians who "discovered themselves to be Black" face, just like me. While I self-identify as Black (that explains the Black-themed books on my bookshelf), Diana does not self-identify as "índia". Despite this fact, when she took the lead in incorporating "Carnaval Arequipeño" into the Grupo Sayari's repertoire, she publicly acknowledged Indigenous culture as part of her Arequipeña identity. By doing so, Diana also expanded the representation of peruanidad in Rio de Janeiro.

The racialization experienced by Diana, Ketty, and Luis Fernando when they are identified as "Indian" indicates that Brazilian racial categories impact upon their migratory experience. It also demonstrates how Brazilian society imagines and treats the country's own Indigenous populations. Krenak (2019) warns of the urgent need to incorporate racism into the debates regarding Indigenous issues in Brazil. He points out that an exclusive focus on ethnicity is not capable of recognizing that Indigenous populations were the first to be affected by the genocidal colonial project still at large in the world. As they move through middle class neighborhoods and occupy spaces of power, such as universities, Peruvians face different forms of discrimination. Being called an "índio", in spite of how they self-identify, is one of these. It is a way of exotizing Peruvians or of calling into doubt their intellectual capacities, projecting onto these immigrants stereotypes that also affect Native Brazilians. The anti-Indigenous racism to which Peruvians are exposed is often not even verbalized. Even silent, it insidiously attacks through hostile looks, displays of disgust, and paternalistic behavior.

Thus, Peruvians experience the migratory experience as "colonial immigrants" (Grosfoguel and MaldonadoTorres 2008). They are immigrants positioned in the area of non-being, in the position of national racialized populations in this case: Native Brazilians. Their processes of racialization, however, are not experienced in the same way. Luis Fernando, for example, can escape racialization by hiding his nationality since his body is socially read as white. Diana and Ketty don't have that option. The "indio" category is used within the Peruvian community in Rio de Janeiro, reproducing the racialization processes in Peru. Many Peruvians who are phenotypically close to their Indigenous ancestors, come from the lower classes living on the outskirts of Lima or were born in Peru's Sierra, suffer from discrimination in the Peruvian immigrant community itself or feel excluded from the peruanidad performed in Peruvian public events in Rio de Janeiro. In dialogue with Carioca society, this peruanidad often takes on stereotyped forms that contribute to reinforce discrimination. 
However, Peruvians in Rio de Janeiro do not completely ignore anti-Black and anti-Indigenous discrimination in both countries. For example, the performance of the poem "Me gritaron negra" and the event "Dialogues from el Sur: Discussing racism in Latin America" put racism on the ag.

Movements against structural racism and the political construction of ethnic-racial identities in Brazil also affect how Peruvians understand race. When Ketty was asked if she would apply for the quotas for Indigenous people in an Anthropology master's selection process, she encountered the term "Indigenous" as potentially applied to herself. In the political organization of Brazilian Indigenous populations, this category is reframed. A category that originally represented colonial domination is thus assumed as an ethnic and political identity: self-identification based on the capacity for self-definition (Hill-Collins 2016), a driving force for emancipation (Segato, 2010). Ketty did not apply for the quota. She did not identify herself as "Indigenous". However, the question generated a profound reflection on her place in Brazil, Peru, and the world. The question made Ketty aware of race not only as a criterion of oppression, but as a political identity. Ketty and I, two negatively racialized researchers, used our agency to transform our pains into action and analysis. From a decolonial perspective, we took our individual feelings and experiences as a source of theoretical reflection, engaging in our own experience of the Afro-Indigenous as a process of becoming (Mello, 2014; Goldman, 2014) - a form of action that reveals the (un)spoken veiled racism (Gonzalez 1988) in Latin America. I close this text, certain and hopeful that it does not end the debate, but opens up spaces for transnational and inter-ethnic anti-racist dialogue.

Received: May 31, 2020

Approved: September 02, 2020

Translated by: Thaddeus Gregory Blanchette

\section{Bibliography}

AIRE, Ketty. 2017. Migração e Identidade: um estudo sobre os andinos no Rio de Janeiro. Master's Dissertation, Universidade Federal do Rio de Janeiro - Rio de Janeiro.

ALTAMIRANO, Teófilo. 200o. Liderezgo y organizaciones de peruanos en el exterior: cultura transnacionales e imaginários sobre el desarrollo. v. 1. Lima: Pontifícia Universidad Católica del Perú.

BARTH, Fredrik. 2000. O guru, o iniciador e outras variações antropológicas. Rio de Janeiro: Contra Capa.

BENTO, Maria A. S. 2014. “Branqueamento e branquitude no Brasil”. In: I. Carone; M. A. S. Bento (orgs.), Psicologia social do racismo: estudos sobre branquitude e branqueamento no Brasil. Petrópolis: Vozes. pp. 25-58. BERNARDINO-COSTA, Joaze; GROSFOGUEL, Ramon. 2016. "Decolonialidade e perspectiva negra”. Sociedade e Estado, 31(1): 15-24. Available at: http://www.scielo.br/pdf/se/v31n1/0102-6992-se-31-01-ooo15.pdf, accessed on 01/10/2020.

BERG, Ulla. 2016. Sujetos móviles: raza, migración y pertenencia en el Perú y los Estados Unidos. Lima: Instituto de Estudios Peruanos.

BEVILAQUA, Camila. 2017. “'Se Fantasiar de Índio é fácil, ser índio é difícil, tem que estudar muito’: vivências indígenas na cidade do Rio de Janeiro". Anthropológicas, 28(2): 85-111.

BLANCHETTE, Thaddeus. 2001. Gringos. Dissertação de Mestrado. Universidade Federal do Rio de Janeiro Rio de Janeiro.

DA CUNHA, Manuela C. 2009. Cultura com as aspas e outros ensaios. São Paulo: Cosac Naify. 
CONDORI HUAMANI, Julia E.; NINA ESCALANTE, Yenny. 2016. Fiesta y poder en los carnavales de Arequipa contemporánea: 1900 - 1960. Senior thesis. Universidad Nacional de San Agustín - Arequipa.

DANIEL, Camila. 2019. “'Morena': a epistemologia feminista negra contra o racismo no trabalho de campo". Humanidades e Inovação, 16(6): 23-34. Available at https:|/revista.unitins.br/index.php/ humanidadeseinovacao/article/view/1825, accessed on 12/15/2019.

DANIEL, Camila. 2015. "O 'folclórico' das danças folclóricas: a dança como espaço de (re)afirmação de identidade entre peruanos no Rio de Janeiro". In: Contins, M; Penha-Lopes, V.: Rocha, C. M. M.., Religiosidade e Performance. Rio de Janeiro: Mauad X/FAPERJ. pp. 36-46.

. 2017. "Peruanidad(es) no Brasil: a construção identidades na experiência migratória de estudantes peruanos no Rio de Janeiro". Mosaico, 8(13): 140 -160.

. 2013. P'a crecer en la vida: a experiência migratória de jovens peruanos no Rio de Janeiro. Doctoral Thesis, Pontifícia Universidade Católica do Rio de Janeiro - Rio de Janeiro.

DE LA CADENA, Marisol. 2006. “¿Son los mestizos híbridos? Las políticas conceptuales de las identidades andinas". Humanística, 61(1): 51-84. Available at http://www.scielo.org.co/scielo.php?script=sci_ arttext\&pid=S0120-48072006000100003\&lng=en\&nrm=iso, accessed on 1/13/2020.

. 1992. "Las mujeres son más indias: etnicidad y género en una comunidad del Cuzco". Isis

Internacional, 16: s/p. Available at: https://centroderecursos.cultura.pe/sites/default/files/rb/pdf/Las\%2o mujeres\%20son\%2omas\%2oindias.pdf, accessed on 1/13/2020.

DEGREGORI, Carlos I. 2012. "Panorama de la antropología en el Perú: del estudio del Otro a la construcción de un Nosotros diverso". In: C. I. Degregori (ed.), No hay país más diverso: compendio de Antropología Peruana. $2^{\underline{a}}$ ed. Lima: IEP. pp. 20-72.

. 1986. "Del mito de inkarri al mito del progreso: Poblaciones andinas, cultura e identidad nacional". Socialismo y Participación, 36: 30 -54.

EGUREN, Fernando. 2015. “Campesino, indígena o agricultor familiar?”. La Revista Agraria, 1: 7-9. GOLDMAN, Marcio. 2015. “Quinhentos anos de contato': por um teoria etnográfica da (contra)mestiçagem”. Mana, 21(3): 641-659. Available at http://www.scielo.br/scielo.php?script=sci_arttext\&pid=So10493132015000300641\&lng=en\&nrm=iso, accessed on 15/12/2020.

. 2014. "A relação afroindígena". Cadernos de Campo, 23(23): 213 -222. Available at http:/|www.revistas. usp.br/cadernosdecampo/article/view/98442/pdf, accessed on 6/10/2020.

GOLTE, Jürgen. 1995. “Nuevos actores y culturas antiguas”. In: J. Cotler (org.), Perú: 1964-1994. Lima: IEP. pp. 23-58.

GONZALEZ, Lélia. 1988. "A categoria político-cultural de amefricanidade". Tempo Brasileiro, 92/93(1): 69-82.

GREENE, Shane. 2010. "Entre lo indio, lo negro y lo incaico: la jerarquía espacial de la diferencia en el Perú multicultural”. Tábula Rasa, 13(1): 111-146.

GROSFOGUEL, Ramon. 2016. “What is racism?”. Journal of World-System Research, 22(1): 9-15. Available at: https://jwsr.pitt.edu/ojs/index.php/jwsr/article/view/6o9, accessed on 10/26/2019.

GROSFOGUEL, Ramon; MALDONADO-TORRES, Nelson. 2008. "Los latinos, los migrantes y la descolonización del imperio estadounidense en el siglo XXI". Tabula Rasa, 9: 117 - 130.

HARRISON, Faye. 1995. "The persistent power of 'race' in the cultural and political economy of racism". Annual Review of Anthropology, 24: 47-74.

HILL-COLLINS, Patricia. 2016. "Aprendendo com a outsider within: a significação sociológica do pensamento feminista negro". Sociedade e Estado, 31(1): 99-127. Available at: http://www.scielo.br/pdf/se/ v31n1/0102-6992-se-31-01-00015.pdf, accessed on 7/10/2019.

HOOKS, bell. 2010. Vivendo de amor. 9 de março de 2010. Available at: <https:||www.geledes.org.br/vivendode-amor/>. Accessed on 8/27/2019. 
INSTITUTO NACIONAL DE ESTADÍSTICA Y INFORMÁTICA (INEI) et al. 2012. Perú: estadísticas de la emigración internacional de peruanos e inmigración de extranjeros, 1990-2011. Lima: OIM.

KRENAK, Ailton et al. 2019. "Existência e diferença: o racismo contra os povos indígenas". Direito Práxis, 10(3): 2161-2181. Available at: www.scielo.br/scielo.php?script=sci_arttext\&pid=S2179$89662019000302161 \& \operatorname{lng}=$ en\& $\mathrm{nrm}=$ iso, accessed on $1 / 20 / 2020$.

McCALLUM, Cecilia; RESTREPO, Eduardo; REESINK, Edwin B. 2017. "Apresentação do Dossiê - Racismo no plural nas Américas: povos indígenas e afro-indígenas”. Anthropológicas, 28(2): 1-5.

MELLO, Cecília. 2014. "Devir-afroindígena: 'então vamos fazer o que a gente é”'. Cadernos de Campo, 23(23): 223-239. Available at: http://www.revistas.usp.br/cadernosdecampo/article/view/98443/pdf_1, accessed on 6/12/2020.

QUIJANO, Aníbal. 2000. “Colonialidad del poder, eurocentrismo y América Latina”. In: E. Lander (comp.), La colonialidad del saber: eurocentrismo y ciencias sociales. Buenos Aires: CLACSO. pp. 201-246. Available at: http://biblioteca.clacso.edu.ar/clacso/se/20140507042402/eje3-8.pdf, accessed on 12/20/2019.

PÆRREGAAD, Karsten. 2008. Peruvians dispersed: a global ethnography of migration. Plymouth: Lexington Books.

PEIXOTO, Kércia P. F. 2017. “Racismo contra indígenas: reconhecer é combater”. Anthropólogicas, 21(28): 27-56. Available at https://periodicos.ufpe.br/revistas/revistaanthropologicas/article/view/25363, accessed on $4 / 12 / 2020$.

ROCHA, Luciane. 2014. Outraged mothering: Black women, racial violence, and the power of emotions in Rio de Janeiro's African Diaspora. Doctoral Thesis, University of Texas Austin.

SANTANA, Bianca. 2015. Quando me descobri negra. São Paulo: SESI-SP.

SAYAD, Abdelmalek. 1999. "Immigration et 'penséss d'État". Actes de la Recherche en Sciences Sociales, 129(1): 5-15. . 1998. A imigração ou os paradoxos da alteridade. São Paulo: EdUSP.

SEGATO, Rita L. 2010. "Los cauces profundos de la raza latinoamericana: una relectura del mestizaje". Crítica e Emancipação, s/n.:11-44. Available at: http://biblioteca.clacso.edu.ar/ojs/index.php/critica/article/ view/166, accessed on 10/07/2019.

. 2005. "Raça é signo". Departamento de Antropologia da Universidade de Brasília, 372: 1-16. Available at: http://www.direito.mppr.mp.br/arquivos/File/segatoracaesigno.pdf, accessed on 9/23/2019.

SOUZA, Neusa S. 1983. Tornar-se negro: as vicissitudes da identidade do negro brasileiro em ascensão social. Rio de Janeiro: Edições Graal.

SEYFERTH, Giralda. 1997. “A assimilação dos imigrantes como questão nacional”. Mana, 3(1): 95-131. . 1996. "Construindo a nação: hierarquias raciais e o papel do racismo na política de imigração e colonização". In: M. Maio e R. Santos (orgs.), Raça, ciência e sociedade. Rio de Janeiro: Fiocruz. pp. 41-58. VIEIRA, Camila. 2014. "Migrações internacionais contemporâneas: os equatorianos na cidade do Rio de Janeiro”. Percursos, 15(28): 310-336. Available at: http:/|www.periodicos.udesc.br/index.php/percursos/ article/view/1984724215282014310, accessed on 1/15/2020.

\section{Camila Daniel}

Rural Federal University of Rio de Janeiro, Departament of Administrative and Social Sciences, Brazil https://orcid.org/oooo-0003-1199-2028

Email: camiladaniell@gmail.com 